\title{
FEATURES OF INTERNATIONAL PROCEDURES OF HUMAN RIGHTS PROTECTION*
}

\section{R. G. Paraschiv}

\author{
Ramona Gabriela Paraschiv \\ Faculty of Law and Administrative Sciences \\ "Dimitrie Cantemir" Christian University \\ *Correspondence: Ramona Gabriela Paraschiv, Lecturer Professor Phd, "Dimitrie Cantemir" \\ Christian University, Splaiul Unirii Street, No.176, Bucharest, Romania \\ E-mail: ramonaparaschiv@ rocketmail.com
}

\begin{abstract}
The idea of developing mechanisms to protect human rights emerged with the Declaration of the Rights of Man and of the Citizen of French National Assembly, on August 26, 1789, which states that "the purpose of all political association is the preservation of the natural and imprescriptible rights of man”. State Concerns for the international protection of human rights have increased but from the second half of the twentieth century, after the establishment of the United Nations Organization, who proposed that one of the aims to be achievement of international cooperation in promoting and encouraging respect for fundamental rights and freedoms of man, thus spurring the creation of protective mechanisms at global and regional levels, able to control the actual translation of regulations enshrining rights.
\end{abstract}

Key words: human rights, protection mechanisms, protection procedures, non-judicial, judicial procedures

\section{Introduction}

Atrocities during the Second World War required a new approach on human rights protection mechanisms ${ }^{1}$, namely their approach internationally, their perfecting becoming a major imperative of the world community ${ }^{2}$.

Mechanisms for promoting and guaranteeing the rights and fundamental freedoms is based on rulemaking activities in the field, the observance of which is achieved through a comprehensive institutional cooperation within organizations and institutions with a universal vocation, regional and national, using a variety of procedures $^{3}$.

States commit by international treaties to respect certain rights of persons under their jurisdiction to the international community, thereby creating an international public order.

\footnotetext{
* This paper has been financially supported within the project entitled "Horizon 2020 - Doctoral and Postdoctoral Studies: Promoting the National Interest through Excellence, Competitiveness and Responsibility in the Field of Romanian Fundamental and Applied Economic Research", contract number POSDRU/159/1.5/S/140106. This project is co-financed by European Social Fund through Sectoral Operational Programme for Human Resources Development 2007-2013. Investing in people!"

${ }^{1}$ Adrian NĂSTASE, Bogdan AURESCU, Cristian JURA, Drept internaţional public, All Beck Publishing House, Bucharest, 2003, p. 194.

${ }^{2}$ Ionel CLOŞCĂ, Ion SUCEAVĂ, Tratat de drepturile omului, Europa Nova Publishing House, Bucharest, 1995, p. 31.

${ }^{3}$ Nicolae PURDĂ, Nicoleta DIACONU, Protecţia juridică a drepturilor omului, Second edition supplemented and amended, Universul Juridic Publishing House, Bucharest, 2011, pp. 110.
} 


\section{R. G. Paraschiv}

To ensure the international protection of human rights, legal norms establish a set of procedures, which run in front of specialized international organizations ${ }^{4}$. The internal organs of the states, which have responsibilities in this area, are also integrated into the organisms that contribute to the observance of human rights, so that their specific activities are performed in accordance with the general procedures designed to protect the rights.

By nature, the procedures for monitoring the way in which human rights are respected are: non-judicial (characteristic mainly to universal system of rights protection) and judicial (specific to regional systems $)^{5}$.

\section{International non-judicial procedures for the protection of human rights}

Non-judicial Control, which may be administrative or political, are carried out internationally by: state reports, reports of body control, notifications (state, individual, collective, internal of organs or international organizations), surveys, general observations, advisory opinions or political and diplomatic means.

a) Control by the reports of States parties to the relevant conventions allow the competent body to make an analysis of the general situation on human rights, based on data provided by the report states.

This non-judicial technique of human rights protection is the most commonly used being promoted mainly by universal conventions in the field, without being ignored by regional conventions.

The state report remains the common law technique, the control technique in the application of human rights ${ }^{6}$, which can perform a periodic assessment of the results obtained internally and specific national policy guidance.

Reporting is entrusted to states that pledged by international conventions to provide information on legislative, administrative or judicial measures taken to implement the provisions of the conventions governing human rights.

When the state becomes a party to an international convention specialized in human rights is prepared the first state report (also called initial report), which presents the promotion and observance of human rights at that time, in that State. At regular intervals state reports show the progress made by the state in promoting human rights. Such reports can be produced on demand by the control body, targeting human rights situation in certain respects.

Control on how human rights protection belongs to administrative law when analyzing reports from the state is entrusted to an independent body, and when it is entrusted to an intergovernmental body, the control is political.

The existence of this form of control does not constitute grounds for inadmissibility of a referral on a case of human rights violations on the grounds of res judicata, so that the referral can be analyzed when this case is governed by state party conventions.

b) Control by using control body reports supposes the existence of specialists in international bodies that carry out checks on how to respect human rights in the countries party to certain agreements in this field.

Reports of control bodies active in the field of human rights are annual and are based on spot checks conducted by representatives and are addressed to the body which compiles them, but can also take the form of general comments based on state reports

c) Control performed following complaints (referrals) implies an advanced non-judicial procedure of international control over how states comply with human rights obligations; they

\footnotetext{
${ }^{4}$ Corneliu-Liviu POPESCU, Protecţia internaţională a drepturilor omului - surse, instituţii, proceduri, All Beck Publishing House, Bucharest, 2000, pp. 16 and fol.

${ }^{5}$ Frédéric SUDRE, Drept european şi internaţional al drepturilor omului (translation), Polirom Publishing House, Iaşi, 2006, p. 495.

${ }^{6}$ Pierre-Marie DUPUY, Droit international public, Sixth edition, Dalloz, Paris, 2002, p. 244.
} 
provide individualized research of cases involving alleged violations of rights, with the consent of the states concerned.

This way of checking facts relate to concrete facts that consist of violation of human rights express contractual obligation invoked by a State Party to the Convention against another State. This procedure, however, can be triggered by an individual against a State Party, by collective subjects or by internal referrals of organs belonging to international organizations that are requesting control.

- Control generated state referrals also contributes to international public policy defense created by human rights norms.

Internationally there is no body with the role of public prosecution, as there are internal, so to promote "public action" for human rights violations, to find the solution of any state recognition of an international convention, a right to sue against another State Party, on which it is assumed that the rights enshrined in the Convention are not observed. Thus, states are supervising each other in the issue of human rights, acting not for their own interest, but in the interest of other States party to the international convention.

- Overall control of individual claims is the most effective non-judicial international procedure for verifying compliance by states of human rights obligations, as it allows direct access of victims to an international body to control how to observe the rights enshrined in international conventions.

While state notifications can cover both general situations of alleged breaches of human rights and particular situations, individual complaints aim, in general, the particular circumstances of failure of one or some of the rights guaranteed to a particular individual or to a group of individuals.

- Overall control of collective complaints on human rights violations is triggered upon notification of some collective subjects belonging to the domestic legal system without public powers but with right to social action.

- Control generated by internal referrals regarding violation of human rights can be triggered by internal organs of an international organization in which it shall exercise control, such as, for example, checking triggered by an internal organ of the International Labor Organization.

d) Control by surveys is a way of checking how to ensure the protection of human rights carried out by specialized bodies. This involves visits by working groups (restricted collectives) or Special Rapporteurs who have the task of examining the human rights situation in a particular State Party to the International Convention. Also check may relate to compliance with a particular law by all States Parties to the Convention or certain members of an international organization.

e) Control by general observations is achieved by interpreting of the control body in the abstract, with respect to certain provisions of the conventional instrument whose application it monitors this organ. Interpretation is made as a guide for countries party to the international convention as it lays down rules regarding the rights shown in the convention and the means to enforce them.

f) Control by advisory opinions is generally a matter for regional international tribunals, specialized in human rights.

This monitoring procedure of how to respect human rights is of conventional nature and does not produce binding legal effects.

Advisory jurisdiction of international regional tribunals specialized in human rights cannot conflict with their judicial power, cannot replace it and cannot prevail against it. Therefore, requests for advisory opinions to the international specialized regional courts are admissible only if they refer to cases relating to disputes within the jurisdiction of that court or organ with which it forms a system. 


\section{R. G. Paraschiv}

g) Control by political and diplomatic means is through the political organs of international organizations that are concerned with human rights through monitoring, resolutions, declarations and other such means, under the Treaties constituents of the organization or based on internal documents adopted by them.

\section{International judicial procedures to protect human rights}

Judicial review, as described in the whole doctrine, can take two forms: one triggered by state demands and one triggered following the individual applications (complaints).

International judicial procedures to protect human rights are pending before international tribunals or bodies forming with them a system.

From the point of view of international judicial body that can resolve the causes of human rights violations are:

- Proceedings before international tribunals specializing in human rights or international parajudicial bodies;

- Proceedings before certain international courts not specialized in human rights.

Specialized international tribunals in human rights are only regionally operating today: The European Court of Human Rights, Inter-American Court of Human Rights and the African Court on Human and Peoples Rights.

As a non-specialized international courts on human rights, but of importance, by their jurisprudence on this issue, we remember: the International Court of Justice, the Court of Justice of the European Union, ad hoc international criminal tribunals (the Nuremberg, Tokyo, for the former Yugoslavia for Rwanda, etc.) and the International Criminal Court, which have jurisdiction in the strict-sense international crimes, most of them covering violation of human rights ${ }^{7}$.

Apart from the foregoing judicial proceedings, protection of human rights is also achieved through parajudicial and execution procedures carried out in front of organs that are in the same system with certain specialized tribunals in human rights. Parajudicial procedures are conducted in front of international bodies such as the Committee of Ministers of European Council (the substantive decision-making powers) and the Inter-American Commission on Human Rights and execution proceedings are carried before international execution bodies, such as the Committee of Ministers of European Council, which has responsibilities in the execution of judgments of the European Court of Human Rights.

\section{Conclusions}

In international law, human rights protection activities are procedural, as conferring the ability to trigger different procedures with the participation of international bodies, as in most cases, a right to control and less judicial one, which is the essence of law of the states.

Non-judicial control procedures are diverse and generally impose burdens states concerned: to assess by reports, how to respect the rights enshrined in the conventions joined, or to cooperate with international committees to verify claims initiated by other States Parties or by some individuals (within their jurisdiction) to determine possible violations of human rights and the measures to be taken to remedy these violations. Non-judicial control has the advantage that does not affect in any way the sovereignty of states by the methods and procedures used, and the solutions are accepted in principle by the States Parties, being taken amicably and through their involvement in the verification activities performed.

Judicial review has the advantage that is achieved through the effective protection of human rights, rulings being legally binding. This procedure, however, requires time and a

\footnotetext{
${ }^{7}$ Daniel-Ştefan PARASCHIV, Gavril PARASCHIV, Ramona-Gabriela PARASCHIV, „Evoluţia pedepselor în dreptul intern şi internaţional penal. Reflecţii critice privind noul Cod penal”, Pro Universitaria Publishing House, Bucharest, 2014, p. 145.
} 
large amount of work by international judicial bodies, involving many people and great expenses $^{8}$, while non-judicial control requires less effort and expense, sometimes contributing to strengthening the accountability of States Parties, provided their involvement in application of human rights regulations and compliance with measures taken that are not binding.

Since there are currently governed by certain conventions, procedures of uncorrelated protection and relatively different, which are made of a variety of disparate organizations and bodies, specialized or which have responsibilities related to this matter, it is necessary to conduct an exhaustive institutional structures, consisting of international bodies (universal and regional) and national integrated to take measures to ensure optimal conditions required for the human rights and carry out effective procedures, designed to investigate how to respect the rights, but the facts that they are injured, having the necessary measures to defend the legal order in this area.

\section{References}

1. Adrian NĂSTASE, Bogdan AURESCU, Cristian JURA, Drept internaţional public, All Beck Publishing House, Bucharest, 2003;

2. Corneliu-Liviu POPESCU, Protecţia internaţională a drepturilor omului - surse, instituţii, proceduri, All Beck Publishing House, Bucharest, 2000;

3. Daniel-Ştefan PARASCHIV, Gavril PARASCHIV, Ramona-Gabriela PARASCHIV, „Evoluţia pedepselor în dreptul intern şi internaţional penal. Reflecţii critice privind noul Cod penal", Pro Universitaria Publishing House, Bucharest, 2014;

4. Frédéric SUDRE, Drept european şi internaţional al drepturilor omului (translation), Polirom Publishing House, Iaşi, 2006;

5. Ionel CLOŞCĂ, Ion SUCEAVĂ, Tratat de drepturile omului, Europa Nova Publishing House, Bucharest, 1995;

6. Nicolae PURDĂ, Nicoleta DIACONU, Protecţia juridică a drepturilor omului, Second edition supplemented and amended, Universul Juridic Publishing House, Bucharest, 2011;

7. Pierre-Marie DUPUY, Droit international public, Sixth edition, Dalloz, Paris, 2002.

\footnotetext{
${ }^{8}$ Frédéric SUDRE, [5], p. 415.
} 